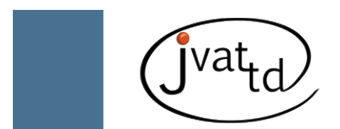

\title{
Biological properties of medicinal plants: a review of their antimicrobial activity
}

Silva NCC (1), Fernandes Júnior A (1)

(1) Department of Microbiology and Immunology, Botucatu Biosciences Institute, São Paulo State University (UNESP Univ Estadual Paulista), Botucatu, São Paulo State, Brazil.

\begin{abstract}
Plants have been used for thousands of years to flavor and conserve food, to treat health disorders and to prevent diseases including epidemics. The knowledge of their healing properties has been transmitted over the centuries within and among human communities. Active compounds produced during secondary vegetal metabolism are usually responsible for the biological properties of some plant species used throughout the globe for various purposes, including treatment of infectious diseases. Currently, data on the antimicrobial activity of numerous plants, so far considered empirical, have been scientifically confirmed, concomitantly with the increasing number of reports on pathogenic microorganisms resistant to antimicrobials. Products derived from plants may potentially control microbial growth in diverse situations and in the specific case of disease treatment, numerous studies have aimed to describe the chemical composition of these plant antimicrobials and the mechanisms involved in microbial growth inhibition, either separately or associated with conventional antimicrobials. Thus, in the present work, medicinal plants with emphasis on their antimicrobial properties are reviewed.
\end{abstract}

Key words: medicinal plants, phytochemistry, antimicrobial activity, plant extracts, essential oils, synergism.

\section{INTRODUCTION}

The use of plants for treating diseases is as old as the human species. Popular observations on the use and efficacy of medicinal plants significantly contribute to the disclosure of their therapeutic properties, so that they are frequently prescribed, even if their chemical constituents are not always completely known. All over the globe, especially in South American countries, the use of medicinal plants has significantly supported primary health care (1). From 250 to 500 thousand plant species are estimated to exist on the planet, and only between 1 and 10\% are used as food by humans and other animals (2). Brazil has the world's highest biodiversity, accounting for over $20 \%$ of the total number of known species. This country presents the most diverse flora, with more than 55 thousand described species, which corresponds to $22 \%$ of the global total. Such biodiversity is followed by a wide acceptance of the medicinal plant use (3). Most of the Brazilian population (80\%) consumes only $37 \%$ of the commercially available drugs and depend almost exclusively on medicines of natural origin (4). Thus, phytotherapics entered the market promising a shorter and cheaper production, since basic requirements to use medicinal plants do not involve strict quality control regarding safety and efficacy compared to the other types of drugs (5).

Infectious diseases represent an important cause of morbidity and mortality among the general population, particularly in developing countries. Therefore, pharmaceutical companies have been motivated to develop new antimicrobial drugs in recent years, especially due to the 
constant emergence of microorganisms resistant to conventional antimicrobials. Apparently, bacterial species present the genetic ability to acquire and transmit resistance against currently available antibacterials since there are frequent reports on the isolation of bacteria that are known to be sensitive to routinely used drugs and became multiresistant to other medications available on the market $(6,7)$. Consequently, common strategies adopted by pharmaceutical companies to supply the market with new antimicrobial drugs include changing the molecular structure of the existing medicines in order to make them more efficient or recover the activity lost due to bacterial resistance mechanisms (8).

On the other hand, given the search for new antimicrobials, those of plant origin must be emphasized since Brazil possess such great biodiversity among which a large number of plants have been used for diverse purposes and tested throughout the globe for hundreds of years by different populations.

\section{ANTIMICROBIAL PROPERTIES OF MEDICINAL PLANTS}

The antimicrobial actions of "carqueja" (Baccharis trimera Less.) decoction on grampositive (Staphylococcus aureus and Streptococcus uberis) and gram-negative (Salmonella gallinarum and Escherichia coli) bacterial strains were evaluated and it was found that the former microorganisms are more sensitive to this herb than the latter, which corroborates previous studies (9). Similarly, antimicrobial assays with plant extracts used in Asia (Ruta graveolens and Zingiber officinale) revealed an inhibitory capacity against Bacillus cereus strains (10).

In another study, the inhibitory activity of concentrates from 14 Brazilian plants against methicillin-resistant Staphylococcus aureus (MRSA) strains was analyzed (11). The substances that demonstrated inhibitory activity were ethanol extract and its fractions (n-hexane, water, chloroform, dichloromethane, ethyl acetate and n-butanol) from Punica granatum fruit (pomegranate) and parts of T. avellanedae wood (purple trumpet tree). The greatest activities were found in the ethyl acetate fraction from $P$. granatum and hexane and chloroform fractions from $T$. avellanedae.

As to the common yarrow (Achillea millefolium), its essential oil (obtained from stem and leaves) presents higher antimicrobial activity than its respective extracts (methanol extract separated by chloroform into parts that were not all soluble). The oils prevented the growth of Streptococcus pneumoniae, Clostridium perfringes and Candida albicans and slightly inhibited Mycobacterium smegmatis, Acinetobacter lwoffi and Candida krussei (12)

A study evaluated the effects of some plant extracts (aqueous and 40\% hydroalcoholic) against bacteria found in the oral cavity of dogs (13). It found that standard S. aureus strain and isolated Streptococcus oralis and Streptococcus mitis strains were sensitive to extracts from garlic (Allium sativum), "espinheira santa" (Maytenus ilicifolia) and guava tree leaves (Psidium guajava).

Similarly, antibacterial properties against Staphylococcus aureus were found in chamomile. The phenolic compounds present in its ethanol extract are responsible for this activity (14). It was also reported that the aqueous extract from the artichoke (Cynara scolymus) and the ethanol extracts (80\%) from both artichoke and "macela" (Achyrocline satureioides) inhibited the growth of Bacillus cereus, B. subtilis, Pseudomonas aeruginosa and $S$. aureus (14). In Argentina, terpene compounds (eugenol, geraniol, thymol and carvacrol) derived from essential oils of native plants showed inhibitory effects on MRSA (15).

In another work, essential oils from 28 plants were tested against ETEC (enterotoxigenic E. coli) and EPEC (enteropathogenic E. coli) serotypes, and the results indicated that palmarosa (Cymbopogon martinii), a highly common plant in Brazil, presents a wide spectrum of action against three ETEC and two EPEC serotypes, whereas Java citronella grass (Cymbopogon winterianus) inhibited one EPEC and two ETEC serotypes (16). The concentration responsible for the microbial inhibition varied between 100 and $500 \mu \mathrm{g} / \mathrm{mL}$, while other plants caused inhibition only at higher concentrations.

Studies on the antimicrobial action of $70 \%$ methanolextractsfromleavesofMikaniaglomerata ("guaco"), P. guajava (guava), Baccharis trimera ("carqueja"), Mentha piperita (peppermint) and Cymbopogon citratus (lemongrass), and $A$. sativum (garlic), Syzygium aromaticum (clove) and Zingiber officinale (ginger) plants in natura were performed all showed some activity against 
S. aureus, and the most effective extracts were those from clove at the concentration of $0.36 \mathrm{mg} /$ $\mathrm{mL}$ and guava at $0.56 \mathrm{mg} / \mathrm{mL}$ (17).

In a study carried out in an indigenous community, it was reported that thehydroalcoholic extracts from Vernonia polyanthes ("assa-peixe"), Aristolochia triangularis ("cipó mil-homens"), Tabebuia avellanedae (purple trumpet tree) and Stryphnodendron adstringens ("barbatimão") presented a significant antimycobacterial effect and that a local beverage, similar to rum (with an ethanol content of 30\%), was employed to prepare the extracts (18).

Furthermore, the results of a recent study described a potent inhibitory activity of Vernonia polyanthes extract against Leishmania strains (19). However, its concentrate had no antifungal action under the same conditions. Similarly, Baccharis dracunculifolia oil ("alecrim-do-campo") at a 10$\mu \mathrm{L}$ dose prevented microbial growth of E. coli, $S$. aureus and $P$. aeruginosa in antimicrobial assays (20).

The essential oils from Pelargonium graveolens (geranium) present low values of minimum inhibitory concentration against $B$. cereus $(0.36$ $\mathrm{mg} / \mathrm{mL})$, B. subitilis $(0.72 \mathrm{mg} / \mathrm{mL})$ and $S$. aureus $(0.72 \mathrm{mg} / \mathrm{mL})$, whereas Origanum vulgare (oregano) oils also show antimicrobial activity against the same bacteria, in addition to E. coli; however, in the latter, a concentration of $0.35 \mathrm{mg} /$ $\mathrm{mL}$ is required to inhibit $B$. subitilis whereas 0.70 $\mathrm{mg} / \mathrm{mL}$ is necessary to inhibit the other bacteria (21).

In a recent study carried out at the Department of Microbiology and Immunology, Botucatu Biosciences Institute, UNESP, tests were performed utilizing extracts from $A$. sativum (bulbs), Z. officinale (rhizomes), Caryophyllus. aromaticus (flower buds), C. citratus (leaves), P. guajava (leaves) and M. glomerata (leaves) against Enterococcus sp., E. coli, S. aureus and Salmonella. The extracts from garlic (A. sativum) and ginger ( $Z$. officinale) presented the most intense activity against gram-negative bacteria; for garlic, concentrations ranged from 1.38 to $1.61 \mathrm{mg} / \mathrm{mL}$ while for ginger it was 6.97 . Grampositive strains were more susceptible to guava extracts at concentrations between 0.77 and 1.74 $\mathrm{mg} / \mathrm{mL}$, and to clove extracts at concentrations from 0.46 to $1.24 \mathrm{mg} / \mathrm{mL}$ (22).

Costa et al. (23) tested the inhibitory capacity of essential oils from Croton zehntneri (wild cinnamon) leaves against Shigella flexneri, Salmonella Typhimurium, E. coli, S. aureus and Streptococcus $\beta$-hemolyticus strains and found antimicrobial activity against all bacteria, except Salmonella. Moreover, the inhibitory action against $S$. flexneri was highly significant, with a minimal inhibitory concentration of $25 \mu \mathrm{g} / \mathrm{mL}$ (23).

Remarkable results using the disc methodology were established in tests on the leaf, phloem and latex of Croton urucurana ("urucuana") against the bacteria Enterococcus faecalis, $S$. aureus, Staphylococcus epidermidis, Streptococcus pyogenes, E. coli, Klebsiella pneumoniae, P. aeruginosa, Salmonella Typhimurium and $S$. flexneri (24). It was found that latex inhibited all tested bacteria except E. coli and showed strong activity against $K$. pneumoniae and $P$. aeruginosa ( 0.125 to $1 \mathrm{mg} /$ disc), whereas leaf hexane extract presented the widest spectrum against gramnegative bacteria and strong action against $K$. pneumoniae and P. aeruginosa $(0.25 \mathrm{mg} / \mathrm{disc})$. The dichloromethane extract was active only against S. pyogenes $(0.5 \mathrm{mg} / \mathrm{disc})$, whereas hydroalcoholic extract acted against gram-positive bacteria and revealed a potent action against Salmonella Typhimurium (0.5 to $1 \mathrm{mg} /$ disc). On the other hand, the ethyl acetate extract was inactive. As to phloem, the hexane and dichloromethane extracts were active against $S$. aureus, S. epidermidis and P. aeruginosa at concentrations from 0.5 to $1 \mathrm{mg} /$ disc; chloroform extract was the most potent against E. faecalis, S. aureus, S. pyognes and $K$. pneumoniae, at concentrations ranging from 0.25 to $1 \mathrm{mg} /$ disc, but was ineffective against $S$. flexneri and Salmonella Typhimurium. Furthermore, ethyl acetate extract presented an antimicrobial effect only against $K$. pneumoniae and S. epidermidis, whereas $75 \%$ ethanol extract had a wide activity against E. faecalis, $S$. pyogenes and $P$. aeruginosa strains; for both extracts the concentration on the disc was between 0.25 and $1 \mathrm{mg}$.

More et al. (25), studying extracts from eight South African plants frequently used against human oral cavity pathogens (Actinobacillus actinomycetemcomitans, Actinomyces naeslundii, Actinomyces israelii, Candida albicans, Porphyromonus gingivalis, Prevotella intermedia and Streptococcus mutans), found that six of the eight plants (Annona senegalensis, Englerophytum magalismontanum, Dicerocarym senecioides, Euclea divinorum, Euclea natalensis, Solanum 
panduriforme and Parinari curatellifolia) had antimicrobial effect against those microorganisms, of which gram-negative ones were more resistant (25).

In another work, the antimicrobial activities of hexane, chloroform, acetone, ethanol, methanol and aqueous extracts from roots and leaves of bushy lippia (Lippia alba) at the concentration of $2 \mathrm{mg} /$ disc were evaluated against $S$. aureus, $B$. subtilis, E. faecalis, Micrococcus luteus, E. coli, P. aeruginosa, Serratia marcescens, Mycobacterium smegmatis, Monilia sitophila and C. albicans (26). The results indicated that chloroform, acetone and ethanol extracts from roots prevented the growth of $S$. aureus, M. luteus, B. subtilis, $M$. smegmatis, $C$. albicans and M. sitophila, while hexane, ethanol and methanol extracts from leaves inhibited S. aureus, M. luteus, B. subtilis, M. smegmatis and M. sitophila.

The ethanol extract from Hyptis martiusii suppressed the growth of E. coli and MRSA strains (at concentrations between 128 and 512 $\mu \mathrm{g} / \mathrm{mL}$ ) and was more effective when compared with gentamicin and methicillin (27). Likewise, the ethanol extract and essential oil from Myrtus communis (myrtle) presented antibacterial effect against $B$. subtilis and $S$. aureus, but not against E. coli (28). Extracts from the peel of Punica granatum fruit (pomegranate) were inhibitory against 38 S. aureus strains (29).

Rosmarinus officinalis Linn. (rosemary) hydroalcoholic extract was assayed against Streptococcus mitis, Streptococcus sanguinis, Streptococcus mutans, Streptococcus sobrinus and Lactobacillus casei standard strains, and its antimicrobial activity was proven in all tests, except against $S$. mitis (30).

Although there are numerous previous studies on medicinal uses of natural products, their applicaton as food additive has only been reported in recent years. Thus, assays with Listeria monocytogenes, S. aureus, E. coli and Salmonella Enteritidis strains isolated from food and essential oils from leaves of oregano, thyme, basil, marjoram, lemongrass, ginger rhizomes and clove flower buds were performed (31). These bacterial strains were susceptible to the oils, among which lemongrass was the most effective against gram-positive microorganisms, followed by clove and ginger; the concentrations (\%v/v) were respectively $0.05,0.09$ and 0.09 . In addition, thyme and clove were the most effective against gram-negative bacteria at the concentration of $0.10 \% \mathrm{v} / \mathrm{v}$. The potential use of these essential oils from aromatic plants to conserve meat and meat derivatives deserves further research.

The hexane, dichloromethane, ethyl acetate and ethanol extracts from phloem of Bowdichia virgilioides ("sucupira"), Calophyllum brasiliense (guanandi), Cariniana rubra ("jequitibá"), Lafoensia pacari ("dedaleira") and Stryphnodendron obovatum; Simaba ferruginea rhizomes; and C. urucurana latex were tested against several bacteria and fungi (32). Ethyl acetate and hexane extracts from $C$. brasiliense phloem showed marked antibacterial activity against gram-positive bacteria such as $S$. aureus, $S$. epidermidis and $S$. agalactiae. Ethyl acetate and ethanol extracts from L. pacari phloem and B. virgilioides extracts produced some effects on fungi. Silva Jr. et al. (32) claimed that it was the first report on antifungal activities of extracts from C. rubra and S. ferruginea.

The antibacterial activity of essential oils from oregano (Origanum vulgare) against multiresistant bacteria - including E. coli, E. faecalis, Acinetobacter baumannii, K. pneumoniae, $P$. aeruginosa and MRSA - was analyzed by Costa et al. (33). Concentrations of at least $0.125 \%$ showed higher antimicrobial efficiency on the studied bacterial strains, although $P$. aeruginosa was found to be more resistant to the essential oil because it was only inhibited at the concentration of $0.5 \%$ (33).

Zampini et al. (34) examined multiresistant bacteria under the influence of ethanol extracts from 11 Argentinean plant species (Baccharis boliviensis, Chiliotrichiopsis keidelii, Chuquiraga atacamensis, Fabiana bryoides, Fabiana densa, Fabiana punensis, Frankenia triandra, Parastrephia lucida, Parastrephia lepidophylla, Parastrephia phyliciformis, and Tetraglochin cristatum). They observed growth inhibition in at least one of the following tested strains: $S$. aureus, E. faecalis, E. coli, K. pneumoniae, Proteus mirabilis, Enterobacter cloacae, Morganella morganii and P. aeruginosa (34).

In another study, essential oils from rosemary (R. officinalis), clove (Caryophyllus aromaticus L.), ginger ( $Z$. officinalis), lemongrass ( $C$. citratus), peppermint (M. piperita) and cinnamon (Cinnamomum zeilanicum Blume) were tested against $S$. aureus and E. coli strains. The oils showed some antimicrobial action; ginger 
essential oil was the most efficient against $S$. aureus while cinnamon and clove were the most effective against $E$. coli at $0.09 \% \mathrm{v} / \mathrm{v}$ (35). Additionally, the cyclohexane extract of Monodora myristica fruit and the ethyl acetate extract from the stem bark of Albizia gummifera were effective in inhibiting C. albicans and Candida krusei (36).

Asin previousstudies, the antimicrobialactivity of essential oils from oregano (Origanum vulgare), thyme (Thymus vulgaris), marjoram (Origanum majorana) and basil (Ocimun basilicum) was evaluated in meat products against strains of $L$. monocytogenes and Salmonella Enteritidis (37). It was reported that all oils showed antibacterial activity and that, particularly, gram-positive bacteria were more susceptive to them.

Based on the aforementioned data, it is possible to conclude that the literature on testing antimicrobial activity of plant products is broad, including an increasing number of publications per year. Therefore, it is difficult to integrate all those numerous studies on the antimicrobial action of plant products into the present review; a multidisciplinary approach to this theme is increasingly required.

\section{INTERACTION BETWEEN NATURAL PRODUCTS AND ANTIMICROBIAL DRUGS}

In addition to the antimicrobial action of plant extracts and essential oils, a synergism between conventional antimicrobial drugs and products obtained from medicinal plants has also been reported. Possible interactions among medications are frequently observed, which has motivated researchers to test such possibilities. However, it must be emphasized that interactions between synthetic and natural drugs depend on several factors including pharmacokinetics and employed doses, since combinations confirmed in vitro may not have the same effect on humans (38). Nevertheless, innumerous studies on this particular theme can be found in the literature.

Synergism assays between terpenes and penicillin against MRSA and E. coli revealed a synergistic effect produced by the combination of carvone and penicillin whereas an antagonistic effect between thymol and penicillin was detected against MRSA strains. Regarding E. coli, synergism was present among penicillin, eugenol and thymol; however, terpene and myrcene only revealed an antagonistic effect (15).
The synergistic effect between plant extracts - clove, jambul (Syzygium cumini), pomegranate and thyme - and some antimicrobial drugs was also evaluated. Garlic extract, when combined with ampicillin, revealed some effects on Klebsiella pneumoniae whereas Proteus sp. growth was inhibited by an association between clove extract and tetracycline. These extracts presented antimicrobial activity, even against microorganisms resistant to antibiotics, thus acting either separately or in association with antibiotics used in conventional therapy (6)

In another study on the interactions between natural products and drugs, synergism was discovered between pairs involving one of eight plant extracts and one of 13 antimicrobial drugs. Furthermore, synergism was also detected in at least two drugs with ginger and 11 drugs with lemongrass and clove when tested against $S$. aureus strains (17). On the other hand, synergism was not observed when this type of study was carried out using E. coli strains; instead, antagonistic reactions were detected (39).

Essential oils from Conyza bonariensis (horseweed), Lippia sidoides (rosemarypepper), Plectranthus amboinicus (mint) and Eucalypthus citriodora (eucalyptus) were studied by Oliveira et al. (40), who aimed to verify synergism of ampicillin, cephalothin, chloramphenicol, gentamicin and tetracycline against S. aureus, S. epidermidis, $P$. aeruginosa and E. coli strains. Ampicillin, cephalothin and tetracycline presented synergistic interactions with the oils whereas gentamicin mostly had antagonistic interactions. Some of the synergisms detected in the study were with L. sidoides oil, which improved the antimicrobial effect of ampicillin and cephalothin against $S$. aureus and S. epidermidis; while C. bonariensis had synergistic action with ampicillin, cephalothin, chloramphenicol and tetracycline against $S$. epidermidis; and P. amboinicus, associated with ampicillin and cephalothin had synergistic action when tested against $S$. aureus and S. epidermidis.

Synergism was also detected in in vitro assays testing interactions between Pelargonium graveolens oil and norfloxacin against $S$. aureus and $B$. cereus, confirming the capacity of that oil to increase the antimicrobial activity of this antibiotic (21).

Fungi have also been evaluated for synergism between natural products and antifungals. 
There were reports of synergism between ketoconazole and Agastache rugosa essential oil against Blastischizomyces capitatus and between Pelargonium graveolens essential oil and amphotericin B plus ketoconazole on strains of Aspergillus sp. (41, 42).

Synergism using different concentrations of commercial oils derived from Melaleuca alternifolia, Thymus vulgaris, M. piperita and $R$. officinalis with ciprofloxacin against $S$. aureus and K. pneumonia, and with amphotericin B against $C$. albicans strains was observed while $R$. officinalis had a predominantly antagonistic profile in combination with with the tested drugs against $S$. aureus and C. albicans strains (43). Synergism was also verified against $K$. pneumoniae while M. alternifolia had a higher level of antagonism than synergism. T. vulgaris presented antagonism against all studied pathogens, and M. piperita revealed synergism against $S$. aureus and antagonism against $C$. albicans. Regarding $K$. pneumonia, the results indicated antagonism or synergism according to the concentration assayed.

Probst (44) reported the antimicrobial action of clove (C. aromaticus), ginger ( $Z$. officinale), peppermint ( $M$. piperita) and cinnamon ( $C$. zeylanicum) essential oils against $S$. aureus and E. coli. Moreover, the interactions of these plants with ethanol extracts of propolis, ginger and mint were synergistic when tested against $S$. aureus whereas against $E$. coli only cloves showed synergism (44).

Synergism between the essentials oils of cinnamon (C. zeylanicum), lemon grass ( $C$. citratus), peppermint (M. piperita), ginger $(Z$. officinale), clove (C. aromaticus) and rosemary $(R$. officinalis) and eight antimicrobial drugs (chloramphenicol, gentamicin, cefepime, tetracycline, sulfazotrim, cephalothin, ciprofloxacin and rifampicin) was tested by the Kirby and Bauer method against strains of $S$. aureus and E. coli. The highest rates of synergism were between lemon grass and the eight drugs tested followed by mint and seven drugs (except cefepime against $S$. aureus). Against E. coli, only rosemary associated with three drugs and lemon grass with two antimicrobials revealed synergism (45).

The interaction of Surinam cherry (Eugenia uniflora), "alecrim-do-campo" (Baccharis dracunculifolia), "assa-peixe" (V. polyanthes) and chamomile ( $M$. chamomilla) with conventional antimicrobial drugs against strains of $S$. aureus was reported and the results are presented in Table 1 (46). In the same study, their interactions against $E$. coli were not relevant, since they presented only three cases of synergism and five of antagonism.

Thus, studies on the interactions between natural products and antimicrobial drugs have also multiplied in recent years, indicating the importance of elucidating those types of interactions, which can be either favorable, such as in synergism, or harmful, as in antagonism. However, such associations, even if beneficial, will not necessarily be used in therapy against infectious diseases, since further studies are still required, especially in vivo studies and research on the toxicity of these products to humans.

Table 1. Results of synergism between plant extracts or essential oils with antimicrobial agents against Staphylococcus aureus strains

\begin{tabular}{c|c|c|c|c|c|c|c|c}
\hline Drugs & \multicolumn{2}{|c|}{$\begin{array}{c}\text { "Alecrim-do- } \\
\text { campo" }\end{array}$} & \multicolumn{2}{c|}{ "Assa-peixe" } & \multicolumn{2}{c|}{ Chamomile } & \multicolumn{2}{c}{ Surinam cherry } \\
\hline & Oil & Extracts & Oil & Extracts & Oil & Extracts & Oil & Extracts \\
\hline Cephalothin & S & I & S & I & I & I & I & I \\
\hline Gentamicin & S & I & S & I & I & I & S & I \\
\hline Tetracycline & S & I & S & I & I & S & I & I \\
\hline Sulfazotrin & S & I & S & I & S & I & S & I \\
\hline Ciprofloxacin & S & I & S & I & S & I & S & I \\
\hline Cefepime & S & I & S & I & I & I & I & I \\
\hline Chloramphenicol & S & I & S & I & I & I & I & I \\
\hline Rifampicin & S & I & S & I & S & S & I & I \\
\hline
\end{tabular}

Synergism was considered positive when $\mathrm{p}<0.05$; S: synergism; I - indifferent.

Source: Silva (46). 


\section{ANTIMICROBIAL ACTIVITY MECHANISMS OF NATURAL PRODUCTS}

Most plants contain several compounds with antimicrobial properties for protection against aggressor agents, especially microorganisms. The chemical structures of some antimicrobial compounds, according to Cowan (2), obtained from plants are shown in Figure 1.
Active compounds found in some plants have antiseptic action; for example, thyme has thymol and carvacrol, clove has eugenol and isoeugenol, and oregano has carvacrol and terpinenol-4. In some cases, terpenes from essences that are soluble in water have higher antibacterial power than others (47).

The sites or structures of the bacterial cell that are considered targets for action by the components of natural products are illustrated

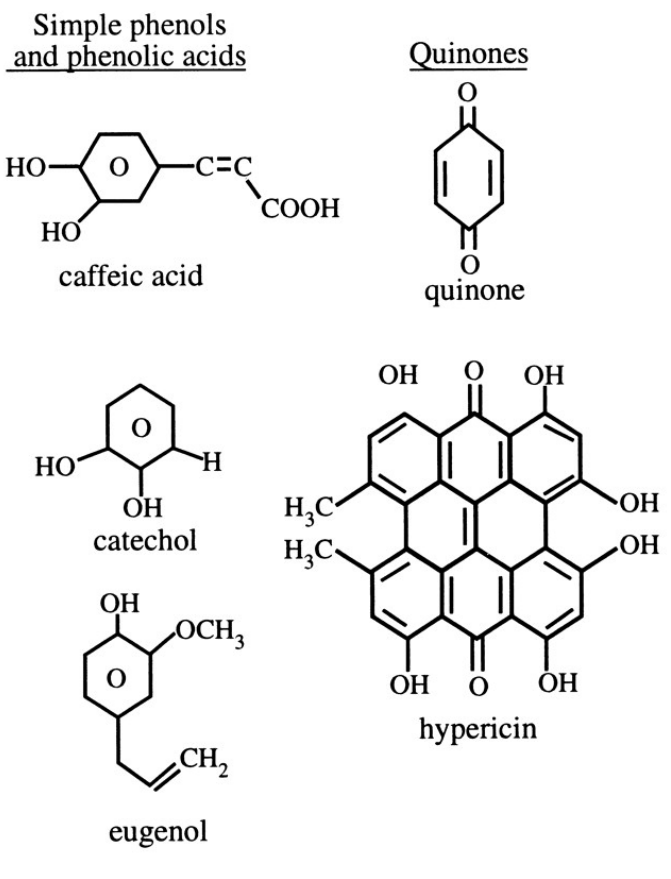<smiles>O=c1cc(-c2ccccc2)oc2ccccc12</smiles>

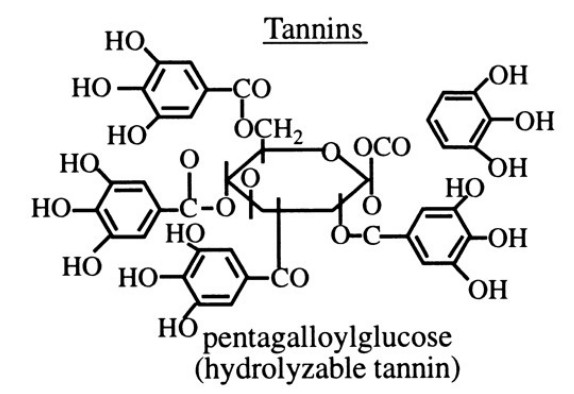

Coumarins<smiles>O=c1ccc2ccccc2o1</smiles>

coumarin<smiles>CCC(=O)CC(c1ccccc1)c1c(O)c2ccccc2oc1=O</smiles>
warfarin Terpenoids<smiles>Oc1cc(O)c2c(c1)O[C@H](c1ccc(O)c(O)c1)[C@H](O)C2</smiles><smiles>O=c1cc(-c2ccccc2)oc2cc(O)cc(O)c12</smiles><smiles>Oc1cc(O)c2c(c1)C[C@@H](O)[C@@H](c1ccc(O)c(O)c1)Oc1cc(O)cc(O)c1C2</smiles>

chrysin (condensed tannin)<smiles>CC(C)C1CC[C@@H](C)CC1O</smiles><smiles></smiles><smiles>OC1C2COC(O)(OC2)C1(O)O</smiles>

fructose<smiles>CC1=C2C[C@H](O)[C@H]3[C@H](OC(=O)C[C@H]3C)C2(C)C=CC1=O</smiles>

artemisin<smiles>O=c1ccc2ccc(O)cc2o1</smiles>

7-hydroxycoumarin<smiles>COc1cc(CNC(=O)CCCC/C=C/C(C)C)ccc1O</smiles><smiles>Cc1nccc2c1[nH]c1ccccc12</smiles>

harmane

Figure 1. Chemical structures of antimicrobial compounds (2). 
in Figure 2. The action mechanisms of natural compounds are related to disintegration of cytoplasmic membrane, destabilization of the proton motive force (PMF), electron flow, active transport and coagulation of the cell content. Not all action mechanisms work on specific targets, and some sites may be affected due to other mechanisms (48).

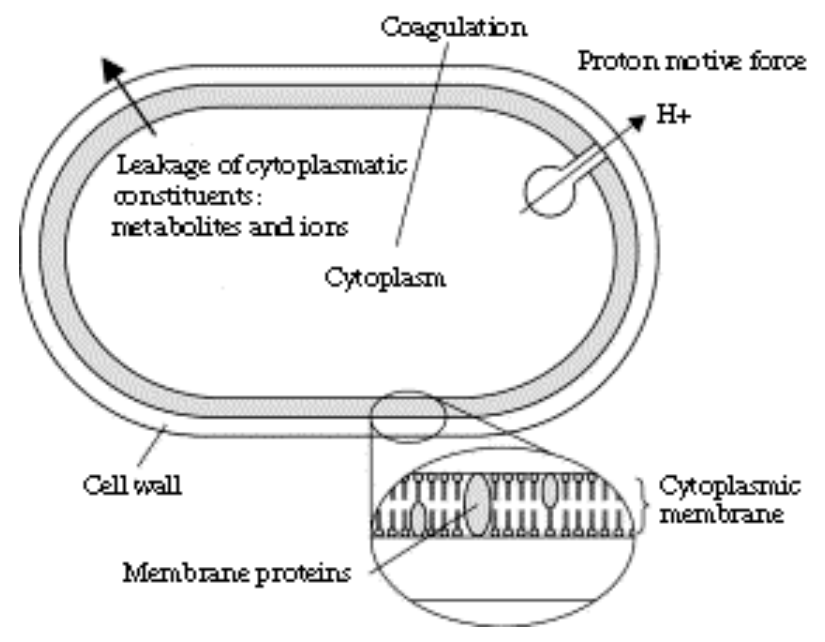

Figure 2. Sites in a bacterium where natural compounds are active (48).

Important characteristics responsible for the antimicrobial action of essential oils include hydrophobic components that allow the participation of lipids from the bacterial cell membrane, which disturbs cell structures and make them more permeable (49).

Chemical compounds from essential oils also act on cytoplasmic membrane proteins (47). Cyclic hydrocarbons act on ATPases, enzymes known to be located at the cytoplasmic membrane and surrounded by lipid molecules. In addition, lipid hydrocarbons may distort the lipid-protein interaction, and the direct interaction of lipophilic compounds with hydrophobic parts of the protein is also possible (50). Some essential oils stimulate the growth of pseudo-mycelia, evidencing that they may act on enzymes involved in the synthesis of bacterium structural components (51).

Several compounds and their mechanisms of action on microorganisms are listed below.

\section{Carvacrol and thymol}

The structure of thymol is similar to that of carvacrol; however, they differ as to the location of the hydroxyl group in the phenolic ring. Both substances seem to make the membrane permeable (52). Their structure disintegrates the external membrane of gram-negative bacteria, releasing lipopolysaccharides (LPS) and increasing the permeability of the cytoplasmic membrane to ATP. The presence of magnesium chloride does not influence this action, suggesting a chelating mechanism of different cations on the external membrane (53).

\section{Eugenol}

Different concentrations of eugenol may inhibit the production of amylase and protease by B. cereus. Furthermore, cell wall degradation and cell lysis were also reported (54).

\section{p-Cymene}

A precursor of carvacrol, this hydrophobic compound provokes greater swelling of the cytoplasmic membrane compared to carvacrol (55).

\section{Carvone}

When tested at concentrations higher than its minimum inhibitory concentration, carvone dissipates gradient $\mathrm{pH}$ and cell membrane potential. The growth of E. coli, Streptococcus thermophilus and Lactococcus lactis may decrease according to the concentrations of carvone, suggesting that it acts by disturbing the general metabolic status of the cell (56).

\section{Cinnamaldehyde}

Cinnamaldehyde is known to inhibit $E$. coli and Salmonella Typhimurium growth at concentrations similar to those of carvacrol and thymol. However, it neither disintegrates the outer membrane nor weakens the intracellular ATP (53). Its carbonyl group has affinity for proteins, preventing the action of decarboxylase amino acids on E. aerogenes (57).

Lastly, Table 2 includes the main action mechanisms of plant antimicrobials according to the groups already mentioned.

\section{FINAL REMARKS}

Since ancient times, plants have been used by several communities to treat a large number of diseases, including infections. Numerous studies on the pharmacology of medicinal plants have been accomplished, since they 
constitute a potential source for the production of new medicines and may enhance the effects of conventional antimicrobials, which will probably decrease costs and improve the treatment quality. However, several plants may present antagonistic effects during antibiotic therapy.

An important aspect comprises the search for new compounds that have antimicrobial action and synergism with currently available antimicrobial drugs, since bacteria resistant to conventional medicines are increasingly frequent; consequently, medicinal plants constitute an alternative for infection treatment.

The antimicrobial activity of plants was proven by various examples, in the form of both essential oils and extracts. Thus, this property can be a promising ally in the development of medicines necessary to combat the increasing number of bacterial strains that become resistant to conventional antibiotics.

Therefore, given that the literature on tests for the antimicrobial action of plant products is broad, including an increasing number of publications per year, it is highly difficult to relate the countless reports on the antimicrobial action of these products in this review article about a subject of such a great complexity, which requires a multidisciplinary approach.

Table 2. Main groups of plant compounds with antimicrobial activity

\begin{tabular}{|c|c|c|c|}
\hline Class & Subclass & Examples & Mechanism \\
\hline \multirow{17}{*}{ Phenolics } & \multirow{2}{*}{ Simple phenols } & Catechol & Substrate deprivation \\
\hline & & Epicatechin & Membrane disruption \\
\hline & Phenolic acid & Cinnamic acid & $?$ \\
\hline & Quinones & Hypericin & $\begin{array}{l}\text { Adhesin binding, complex with cell wall, } \\
\text { enzyme inactivation }\end{array}$ \\
\hline & Flavonoids & Chrysin & Adhesin binding \\
\hline & \multirow{3}{*}{ Flavones } & - & Complex with cell wall \\
\hline & & \multirow{2}{*}{ Abyssinone } & Enzyme inactivation \\
\hline & & & HIV reverse transcriptase inhibition \\
\hline & Flavonols & Totarol & $?$ \\
\hline & \multirow{7}{*}{ Tannins } & \multirow{7}{*}{ Ellagitannin } & Protein binding \\
\hline & & & Adhesin binding \\
\hline & & & Enzyme inhibition \\
\hline & & & Substrate deprivation \\
\hline & & & Complex with cell wall \\
\hline & & & Membrane disruption \\
\hline & & & Metal-ion complexation \\
\hline & Coumarins & Warfarin & $\begin{array}{l}\text { Interaction with eucaryotic DNA (antiviral } \\
\text { activity) }\end{array}$ \\
\hline $\begin{array}{l}\text { Terpenoids, } \\
\text { essential oils }\end{array}$ & - & Capsaicin & Membrane disruption \\
\hline \multirow{2}{*}{ Alkaloids } & \multirow{2}{*}{-} & Berberine & \multirow[t]{2}{*}{ Intercalation into cell wall and/or DNA } \\
\hline & & Piperine & \\
\hline \multirow{2}{*}{$\begin{array}{l}\text { Lectins and } \\
\text { polypeptides }\end{array}$} & \multirow[t]{2}{*}{-} & $\begin{array}{l}\text { Mannose-specific } \\
\text { agglutinin }\end{array}$ & Block of viral fusion or adsorption \\
\hline & & Falxatin & Disulfide bridge formation \\
\hline Polyacetylenes & - & $\begin{array}{l}\text { 8s-heptadeca- } \\
\text { 2(Z),9(Z)-diene- } \\
\text { 4,6-diyne-1,8-diol }\end{array}$ & $?$ \\
\hline
\end{tabular}

Source: adapted from Cowan (2). 


\section{COPYRIGHT}

(C) CEVAP 2010

\section{SUBMISSION STATUS}

Received: May 18, 2010.

Accepted: May 21, 2010.

Abstract published online: June 7, 2010.

Full paper published online: August 31, 2010.

\section{CONFLICTS OF INTEREST}

There is no conflict.

\section{CORRESPONDENCE TO}

ARY FERNANDES JUNIOR, Departamento de Microbiologia e Imunologia, Instituto de Biociências, UNESP, Distrito de Rubião Junior, s/n, Botucatu, SP, 18618-970, Brasil. Phone: +55 143811 6058. Email: ary@ibb.unesp.br.

\section{REFERENCES}

1. Maciel MAM, Pinto AC, Veiga Jr VF, Grynberg NF, Echevarria A. Medicinal plants: the need for multidisciplinary scientific studies. Quim Nova. 2002;25(3):429-38.

2. Cowan MM. Plant products as antimicrobial agents. Clin Microbiol Rev. 1999; 12(4):564-82.

3. Carvalho ACB, Nunes DSG, Baratelli TG, Shuqair NSMSAQ, Machado Netto E. Aspectos da legislação no controle dos medicamentos fitoterápicos. T\&C Amazônia. 2007;5(11):26-32.

4. Funari CS, Ferro VO. Ethical use of the Brazilian biodiversity: necessity and opportunity. Rev Bras Farmacogn. 2005;15(2):178-82.

5. Niero R. Fármacos, fitofármacos e fitoterápicos: abordagem econômica e de mercado. In: Bresolin $\mathrm{TMB}$, Cechinel Filho V, editors. Fármacos e medicamentos. Uma abordagem multidisciplinar. São Paulo: Editora Santos; 2010. p. 1-15.

6. Nascimento GGF, Locatelli J, Freitas PC, Silva GL. Antibacterial activity of plant extracts and phytochemicals on antibiotic-resistant bacteria. Braz J Microbiol. 2000;31(1):247-56.

7. Sakagami Y, Kajimura K. Bactericidal activities of disinfectants against vancomycin-resistant enterococci. J Hosp Infec. 2002;50(2):140-4.

8. Chartone-Souza E. Bactérias ultra-resistentes: uma guerra quase perdida. Cienc Hoje. 1998;23(138):27-35.

9. Avancini CAM, Wiest JM, Mundstock EA. Bacteriostatic and bactericidal activity of the Baccharis trimera (Less.) D.C. Compositae decocto, as disinfectant or antisseptic. Arq Bras Med Vet Zootec. 2000;52(3):230-4.

10. Alzoreky NS, Nakahara K. Antibacterial activity of extracts from some edible plants commonly consumed in Asia. Int J Food Microbiol. 2003;80(3):223-30.

11. Machado TB, Pinto AV, Pinto MC, Leal ICR, Silva MG, Amaral ACF, et al. In vitro activity of Brazilian medicinal plants, naturally occurring naphthoquinones and their analogues, against methicillin-resistant Staphylococcus aureus. Int J Antimicrob Agents. 2003;21(3):279-84.

12. Candan F, Unlu M, Tepe B, Daferera D, Polissiou M, Sokmen A, et al. Antioxidant and antimicrobial activity of the essential oil and methanol extracts of Achillea millefolium subsp. millefolium Afan. (Asteraceae). J Ethnopharmacol. 2003;87(23):215-20.

13. Menezes MC, Souza MMS, Botelho RP. In vitro evaluation of antimicrobial activity of Brazilian plants extracts on bacteria isolated from oral cavity of dogs. Rev Univ Rural. 2004;24(2):141-4.

14. Asolini FC, Tedesco AM, Ferraz C, Alencar SM, Carpes ST. Antioxidant and antibacterial activities of phenolic compounds in extracts of plants used as tea. Braz J Food Technol. 2006;9(6):209-15.

15. Gallucci N, Casero C, Oliva M, Zygadlo J, Demo $\mathrm{M}$. Interaction between terpenes and penicillin on bacterial strains resistant to beta-lactam antibiotics. Mol Med Chem. 2006;10(1):30-2.

16. Duarte MCT, Delarmelina C, Figueira GM, Sartoratto A, Rehder VLG. Effects of essential oils from medicinal plants used in Brazil against EPEC and ETEC Escherichia coli. Rev Bras PI Med. 2006;8(n.esp.):139-43.

17. Betoni JE, Mantovani RP, Barbosa LN, Di Stasi LC, Fernandes Jr A. Synergism between plant extract and antimicrobial drugs used on Staphylococcus aureus diseases. Mem Inst Oswaldo Cruz. 2006;101(4):387-90.

18. Oliveira DG, Prince KA, Higuchi CT, Santos ACB, Lopes LMX, Simões MJS, et al. Antimycobacterial activity of some Brazilian indigenous medicinal drinks. J Basic Appl Pharm Sci. 2007;28(2):165-9.

19. Braga FG, Bouzada ML, Fabri RL, Matos MO, Moreira FO, Scio E, et al. Antileishmanial and antifungal activity of plants used in traditional medicine in Brazil. J Ethnopharmacol. 2007;111(2):396-402.

20. Ferronato R, Marchesan ED, Pezenti E, Bednarski F, Onofre SB. Antimicrobial activity of essential oils produced by Baccharis dracunculifolia D.C. and Baccharis uncinella D.C. (Asteraceae). Rev Bras Pharmacogn. 2007;17(2):224-30.

21. Rosato A, Vitali C, Laurentis N, Armenise D, Milillo MA. Antibacterial effect of some essential oils administered alone or in combination with norfloxacin. Phytomedicine. 2007;14(11):727-32. 22. Ushimaru PI, Silva MTN, Di Stasi LC, Barbosa L, 
Fernandes Jr A. Antibacterial activity of medicinal plant extracts. Braz J Microbiol. 2007;38(1):7179.

23. Costa JGM, Rodrigues FFG, Angélico EC, Pereira CKB, Souza EO, Caldas GFR, et al. Chemical composition and evaluation of the antibacterial activity and toxicity of the essential oil of Croton zehntneri (variety estragol). Rev Bras Pharmacogn. 2008; 18(4):583-6.

24. Oliveira IS, Lima JCS, Silva RM, Martins DTO. In vitro screening of antibacterial activity of the latex and extracts from Croton urucurana Baillon. Rev Bras Pharmacogn. 2008;18(4):587-93.

25. More GK, Tshikalange TE, Lall N, Botha FS, Meyer JJM. Antimicrobial activity of medicinal plants against oral microorganisms. J Ethnopharmacol. 2008;119(1):473-7.

26. Aguiar JS, Costa MCCD, Nascimento SC, Sena KXFR. Antimicrobial activity of Lippia alba (Mill.) N. E. Brown (Verbenaceae). Rev Bras Pharmacogn. 2008; 18(3):436-40.

27. Coutinho HDM, Costa JGM, Siqueira-Júnior JP, Lima EO. In vitro anti-staphylococcal activity of Hyptis martiusii Benth against methicillinresistant Staphylococcus aureus MRSA strains. Rev Bras Pharmacogn. 2008;18(Supl.):670-5.

28. Salvagnini LE, Oliveira JRS, Santos LE, Moreira RRD, Pietro RCLR. Evaluation of the antibacterial activity of Myrtus communis L. (Myrtaceae) leaves. Rev Bras Pharmacogn. 2008;18(2):241-4.

29. Silva MAR, Higino JS, Pereira JV, Siqueira-Júnior JP, Pereira MSV. Antibiotic activity of the extract of Punica granatum Linn. over bovine strains of Staphylococcus aureus. Rev Bras Pharmacogn. 2008;18(2):209-12.

30. Silva MSA, Silva MAR, Higino JS, Pereira MSV, Carvalho AAT. In vitro antimicrobial activity and antiadherence of Rosmarinus officinalis Linn. against oral planktonic bacteria. Rev Bras Pharmacogn. 2008;18(2):236-40.

31. Barbosa LN, Rall VL, Fernandes AA, Ushimaru PI, da Silva Probst I, Fernandes A Jr. Essential oils against foodborne pathogens and spoilage bacteria in minced meat. Foodborne Pathog Dis. 2009;6(6):725-8.

32. Silva Jr. IE, Cechinel Filho V, Zacchino SA, Lima JCS, Martins DTO. Antimicrobial screening of some medicinal plants from Mato Grosso Cerrado. Rev Bras Pharmacogn. 2009;19(1B):242-8.

33. Costa AC, Santos BHC, Santos Filho L, Lima EO. Antibacterial activity of the essential oil of Origanum vulgare L. (Lamiaceae) against bacterial multiresistant strains isolated from nosocomial patients. Rev Bras Pharmacogn. 2009;19(1B):236-41.

34. Zampini IC, Cuello S, Alberto MR, Ordonez
RM, D'Almeida R, Solorzano E, et al. Antimicrobial activity of selected plant species from "the Argentine Puna" against sensitive and multiresistant bacteria. J Ethnopharmacol. 2009;124(3):499-505.

35. Silva MTN, Ushimaru PI, Barbosa LN, Cunha MLRS, Fernandes Jr A. Antibacterial activity of plant essential oils against Staphylococcus aureus and Escherichia coli strains isolated from human specimens. Rev Bras PI Med. 2009; 11(3):257-62.

36. Mbosso EJ, Ngouela S, Nguedia JC, Beng VP, Rohmer M, Tsamo E. In vitro antimicrobial activity of extracts and compounds of some selected medicinal plants from Cameroon. J Ethnopharmacol. 2010;128(2):476-81.

37. Barbosa LN. Propriedade antimicrobiana de óleos essenciais de plantas condimentares com potencial de uso como conservantes em carne e hambúrguer bovino e testes de aceitação [thesis]. Botucatu: Universidade Estadual Paulista, Instituto de Biociências; 2010. 107 p.

38. Szalek E, Grzeskowiak E, Kozielczyk J. Interactions between herbal and synthetic drugs. Advantages and risks. Herba Polonica. 2006;52(4):153-7.

39. Ushimaru PI. Estudo in vitro da atividade antibacteriana de extratos de plantas medicinais e sinergismo com drogas antimicrobianas [thesis]. Botucatu: Universidade Estadual Paulista, Instituto de Biociências; 2007. 51 p.

40. Oliveira RAG, Lima EO, Vieira WL, Freire KRL, Trajano VN, Lima IO, et al. Study of the interference of essential oils on the activity of some antibiotic used clinically. Rev Bras Pharmacogn. 2006;16(1):77-82.

41. Shin S. Anti-Aspergillus activities of plant essential oils and their combination effects with ketoconazole or amphotericin B. Arch Pharm Res. 2003;26(5):389-93.

42. Shin S, Kang CA. Antifungal activity of the essential oil of Agastache rugosa Kuntze and its synergism with ketoconazole. Lett Appl Microbiol. 2003;36(2):111-5.

43. van Vuuren SF, Suliman S, Viljoen AM. The antimicrobial activity of four commercial essential oils in combination with conventional antimicrobials. Lett Appl Microbiol. 2009;48(4):440-6.

44. Probst I. Ação antibacteriana de extrato etanólico de própolis e óleos essenciais de plantas medicinais e sinergismo entre estes produtos naturais. Botucatu: Universidade Estadual Paulista, Instituto de Biociências; 2009. 41 p.

45. Zago JAA, Ushimaru PI, Barbosa LN, Fernandes Jr A. Synergism between essential oils and antimicrobial drugs against Staphylooccus aureus and Escherichia colistrains from human infections. 
Rev Bras Pharmacogn. 2009;19(4):828-33.

46. Silva NCC. Estudo comparativo da ação antimicrobiana de extratos e óleos essenciais de plantas medicinais e sinergismo com drogas antimicrobianas [thesis]. Botucatu: Universidade Estadual Paulista, Instituto de Biociências; 2010. $67 \mathrm{p}$.

47. Knobloch K, Pauli A, Iberl B. Antibacterial and antifungal properties of essential oil components. J Essent Oil Res. 1989;1(3):119-28.

48. Burt S. Essential oils: their antibacterial properties and potential applications in foods - a review. Int J Food Microbiol. 2004;94(3):233-53.

49. Sikkema J, de Bont JA, Poolman B. Interactions of cyclic hydrocarbons with biological membranes. J Biol Chem. 1994;269(11):8022-8.

50. Sikkema J, de Bont JA, Poolman B. Mechanisms of membrane toxicity of hydrocarbons. Microbiol Rev. 1995;59(2):201-22.

51. Conner DE, Beuchat LR. Effects of essential oils from plants on growth of food spoilage yeasts. J Food Sci. 1984;49(2):429-34.

52. Lambert RJW, Skandamis PN, Coote P, Nychas GJE. A study of the minimum inhibitory concentration and mode of action of oregano essential oil, thymol and carvacrol. J Appl Microbiol. 2001;91(3):453-62.
53. Helander IM, Alakomi HL, Latva-Kala K, MattilaSandholm T, Pol I, Smid EJ, et al. Characterization of the action of selected essential oil components on gram-negative bacteria. J Agric Food Chem. 1998;46(9):3590-5.

54. Thoroski J, Blank G, Biliaderis C. Eugenol induced inhibition of extracellular enzyme production by Bacillus cereus. J Food Prot. 1989;52(6):399-403.

55. Ultee A, Bennink MHJ, Moezelaar R. The phenolic hydroxyl group of carvacrol is essential for action against the food-borne pathogen Bacillus cereus. Appl Environ Microbiol. 2002;68(4):1561-8.

56. Oosterhaven K, Poolman B, Smid EJ. S-carvone as a natural potato sprout inhibiting, fungistatic and bacteristatic compound. Ind Crops Prod. 1995;4(1):23-31.

57. Wendakoon CN, Sakaguchi M. Inhibition of amino acid decarboxylase activity of enterobacter aerogenes by active components in spices. J Food Prot. 1995; 58(3):280-3. 